\title{
Draft Statement on the Reproduction of Manuscripts And Archives for Noncommercial Purposes*
}

The following statement will be considered for approval by the Association of College and Research Libraries at the Midwinter Meeting in Chicago, 1974. All comments and suggestions for revision should be sent to Ruth Salisbury, Chairman of the ACRL Rare Books and Manuscripts Section, Historical Society of Western Pennsylvania, 4338 Bigelow Blvd., Pittsburgh, PA 15213, or to Beverly P. Lynch, Executive Secretary, ACRL, 50 E. Huron St., Chicago, IL 60611.

1. It is the responsibility of a library, archives, or manuscript repository to assist qualified researchers, as defined by the respective institutions, by making or having made reproductions of any material in its possession, subject to certain conditions.

Manuscript and archival materials may be reproduced if :

a. the condition of the originals will permit such reproduction

b. the originals have no gift, purchase, or legal restrictions on reproduction

c. the holders of appropriate common law or statutory rights have given their written approval to said reproductions.

2. All conditions relating to use of manuscript or archival materials shall apply to reproductions.

3. No repository shall be required to reproduce a complete manuscript collection or archival record group or extensive portions therefrom, the limitation to be set by the owning repository. The repository may, by a special agreement, do so for the mutual advantage of individuals and other institutions and may offer such copies for sale on its own behalf.

4. The price of reproductions shall be set by the repository, which should endeavor to keep charges to a minimum.

5. Copies should be made for the use of individual researchers and educational institutions as follows:

a. Repositories which permit their manuscript and archival collections to be reproduced in whole or part must specify before the copies are made what restrictions if any have been placed on the use of the copies. Purchasers must abide by these restrictions.

b. All reproductions must identify the source of the original manuscript collection or archival record group.

c. Copies of reproductions should not be made for a third party by the owner of a reproduction without the written permission of the repository owning the originals.

6. The repository must inform the researcher that permission to make extensive direct quotation from or to print in full any reproduction must be obtained from the institution owning the originals. In the case of material under copyright, the right to quote or print must also be obtained by the researcher from the copyright owner. Manuscripts cannot be used for publication without due regard for common law rights, literary rights, property rights, and libel laws. The researcher assumes legal responsibility for observing these rights. A repository should, to the best of its ability, inform the researcher about known retention of literary rights.

\section{Draft Statement on Access to Original Research Materials In Libraries, Archives, and Manuscript Repositories}

The following statement will be considered for approval by the Association of College and Research Libraries at the Midwinter Meeting in Chicago, 1974. All comments and suggestions for revision should be sent to Ruth Salisbury, Chairman of the ACRL Rare Books and Manuscripts Section, Historical Society of Western Pennsylvania, 4338 Bigelow Blvd., Pittsburgh, PA 15213, or to Beverly P. Lynch, Executive Secretary, ACRL, 50 E. Huron St., Chicago, IL 60611.
1. It is the responsibility of a library, archives, or manuscript repository to make available to qualified researchers, as defined by the

- This statement is not applicable to commercial reproduction. A separate statement on commercial publication or reproduction of archival groups and manuscripts is being prepared by the ACRL Rare Books and Manuscripts Section's Committee on Manuscripts Collections. 
respective institutions, on equal terms of access, research materials in its possession. Because the accessibility of material depends on knowing of its existence, it is the responsibility of a repository to inform researchers of the collections in its custody. This may be accomplished through a card catalog, inventories and other internal finding aids, a published guide and reports to NUCMC where appropriate, and the freely offered assistance of staff members.

2. To protect and insure the continued accessibility of the material in its custody, the repository may impose several conditions.

a. The repository may limit the use of fragile or unusually valuable materials so long as suitable reproductions are made available for the use of all researchers.

b. All materials must be used in accordance with the rules of and under the supervision of the repository. Each repository should publish and furnish to potential researchers its rules governing access and use. Such rules must be equally applied and enforced.

c. The repository may refuse access to unprocessed materials, so long as such refusal is applied to all researchers.

d. Normally, a repository will not send research materials for use outside its building or jurisdiction. Under special circumstances a collection or a portion of it may be loaned or placed on deposit with another institution.

e. The repository may refuse access to an individual researcher who has demonstrated such carelessness or deliberate destructiveness as to endanger the safety of the material.

3. Each repository should publish a suggested form of citation crediting the repository and identifying items within the collection for later reference. Citations to copies of materials in other repositories should include the location of the originals.

4. A repository should advise the researcher that he and his publisher have the sole responsibility for securing permission to publish from unpublished manuscripts in which literary property rights are retained or to publish any extensive quotation from copyrighted works. Manuscripts cannot be used for publication without due regard for common law rights, literary rights, property rights, and libel laws. The user assumes legal responsibility for observing these rights.
A repository should, to the best of its ability, inform the researcher about known retention of literary rights.

5. A repository should not grant exclusive use of materials to any person or persons, or conceal the existence of any body of material from any researcher unless required to do so by law, donor, or purchase stipulations.

6. A repository should, whenever possible, inform a researcher of parallel research by other individuals using the same papers. It may supply names upon request.

7. Repositories are committed to preserving manuscript and archival materials and to making them available for research as soon as possible. At the same time, it is recog-

\section{Union Catalog Expands Libraries' Holdings}

A union catalog has been formed between the librarians of Friends University and Sacred Heart College-two small private liberal arts church-related colleges (one Quaker, one Catholic) in Wichita, Kansas. This union catalog is unique in that every card in each school's catalog was reproduced, appropriately marked to identify the library, and then interfiled in the cooperating college's card catalog. This differs from most union catalogs where only the main entry cards are reproduced and interfiled in the other catalog. The philosophy behind this procedure was to provide as much useful information on each title as possible in order to assist the undergraduate student in his library needs.

The completion of this project has now shown that 20 percent of the holdings of the two college libraries is duplication, which means that each library now has additional complete information on 80 percent of a different collection-that of the cooperating school. Put another way, since each college has holdings of 50,000 volumes, the union catalog essentially gives all the information on a $90,000 \mathrm{vol}$ ume collection.

The two libraries are geographically only one mile apart, so there is no great inconvenience. A "hot line" between circulation desks and a book courier provide additional convenience for the library patrons. 
nized that every repository has certain obligations to protect confidentiality in its records in accordance with law and that every private donor has the right to impose reasonable restrictions upon his papers to protect confidentiality for a reasonable period of time.

a. It is the responsibility of the repository to inform researchers of the restrictions which apply to individual collections or record groups. b. The repository should discourage donors from imposing unreasonable restrictions.

c. The repository should, whenever possible, require a specific time limit on all restrictions.

d. The repository should periodically reevaluate restricted records and work toward providing access to material no longer harmful to individuals or to national interest.

\section{News From the Field}

\section{ACQUISITIONS}

- California State University, Fresno, has acquired the archives of Albert Kimsey Owen, founder of the utopian colony at Topolobampo, Sinaloa, Mexico. These archives were given to the University Library, Department of Special Collections, by Mr. Ray Reynolds of San Diego, who obtained them from the Owen family. These archives will be added to a smaller collection of materials on the colony and the Credit Foncier Company of Sinaloa. The smaller collection was given to the university in 1955 by Mrs. Viola Gabriel, of Fresno, who was born in the colony.

The Reynolds collection consists of over ten thousand letters, maps, documents, newspapers, pamphlets, and plans relating to the colony and the Credit Foncier Company. The Gabriel collection contains about eight hundred items of a similar nature, as well as an outstanding collection of nearly 100 photographs.

The combined collection constitutes the larg. est and most complete collection of materials on any American utopian venture of the late nineteenth century.

- The Special Collections of Ganser Library of Milleasville State College, Millersville, Pennsylvania has received the papers of Richard Gehman. Given by his widow, Marianne, the collection includes scrapbooks relating to the publications of his works; original manuscripts of his novels, nonfiction works, and magazine articles, both published and unpublished; correspondence concerning his works; personal diaries; taped interviews with subjects of books and articles; photographs of Gehman during various phases of his life; leather bound copies of his longer books inscribed to Gehman by other authors. A native of Lancaster, Gehman became known as the "King of Freelance Writers," publishing 2,000 to 3,000 magazine ar- ticles; biographies of show business personalities; nonfiction works including Murder in Paradise, How to Write and Sell Magazine Articles, and Let $\mathrm{My}$ Heart Be Broken; and several novels, two of which are Driven and The Had.

- The library of Ohio State University has recently purchased a collection of rare books on the history of geology from Professor George W. White, a distinguished geologist and alumnus of the university. This acquisition constitutes a major addition to the library's holdings in this field and will greatly facilitate studies on the early development of geology here, both by students and faculty.

- Mr. and Mrs. Barry Moyerman and Mrs. Samuel Moyerman of Philadelphia have given to the Hugh M. Morris Library of the UnivenSity of Delaware one of the largest gifts in its history. Over a period of three years the library has added to its collections over 25,000 volumes. The books and pamphlets are particularly rich in local, state, and county histories of the Delaware Valley, directories, almanacs, eighteenth and nineteenth century travel, eighteenth century legal material, American theology, and materials reflecting American economic, political, and social conditions. In addition to the books and other printed and pictorial materials there are approximately 250,000 manuscripts. These papers primarily reflect the economic, social, and artistic life of eighteenth and nineteenth century Pennsylvania and particularly Philadelphia. There are also circa 65,000 items from the Philadelphia Customs House from 1790-1840. Included also are vast numbers of diaries, daybooks, ledgers, recipe books, and receipt books. Besides the books and manuscripts there are large numbers of political and theological broadsides and other ephemeral types of material reflecting all aspects of nineteenth century America. 